\title{
CHANGES IN THE PERIGLACIAL ENVIRONMENT \\ Proceedings of a symposium at Suitia, Siuntio, Finland, October 25-26, 1996, arranged by the Finnish National Committee for Quaternary Research
}

\author{
JOAKIM DONNER and MARJATTA KOIVISTO
}

\begin{abstract}
JOAKIM DONNER and MARJATTA KOIVISTO, 1997: Changes in the Periglacial Environment. Bull. Geol. Soc. Finland 69, Part 1-2, 55.

Keywords: periglacial environment, permafrost, till, sea-level changes, Quaternary, symposia, Finland

Joakim Donner, Department of Geology, P.O. Box 11, FIN-00014 University of Helsinki, Finland

Marjatta Koivisto, Geological Survey of Finland, P.O. Box 96, FIN-02151 Espoo, Finland
\end{abstract}

\section{PREFACE}

The Finnish National Committee for Quaternary Research arranged its first symposium in 1986 on Fennoscandian land uplift. Since then the Committee has arranged biennual symposia on relevant topics. The symposia were held in Finnish, but the talks have been published mainly in English. The series for publication have been: Geological Survey of Finland, Special Paper and Report of Investigation, Acta Universitatis Ouluensis, Series A, and now the Bulletin of the Geological Society of Finland. All symposia have stimulated further research and cooperation between scientists representing different branches of the natural sciences.
This time the symposium was held on October 25-26, 1996, at Suitia, Siuntio, Finland, at a research Station belonging to the University of Helsinki. It is situated $50 \mathrm{~km}$ west of Helsinki in a beautiful Finnish rural landscape, with a manor house dating from the the 15th century.

Professor Joakim Donner was chairman and Dr. Marjatta Koivisto secretary at the meeting. The 20 participants represented geography, geology, geophysics and botany. Eleven talks, of which six articles will be published here, deal with geomorphology in the periglacial environment in Finnish Lapland, chemistry and weathering of glacial tills in Antarctica, permafrost and polygons, nuclear waste disposal and periglacial vegetation in Finnish Karelia. 